\title{
Land Reclamation in Iraq
}

\author{
Kanaan Abduljabar Abu-Gullal', Mukhalad Abdullah ${ }^{2}$ \\ and Nadhir Al-Ansari ${ }^{3}$
}

\begin{abstract}
Reclamation in Iraq was known in 1950s, where the problems salinity and waterlogging are mainly apparent in the middle and south of Iraq. The early interventions in reclamation sectors was simple, not precise, or calibrated properly, hence, salinization and water-logging aggravated.

Since the reclamation activities are time and resources consuming, which may last in several years, these are highlighting the fact that most of the beneficiaries could not afford the conducting of this activity. Therefore, Iraqi government take the decision in 1970s to carry out the reclamation and improve the agricultural processes vertically. There are millions of donums were reclaimed along Iraq.

There are key steps adopted to conduct the sophisticated reclamation in order to get rid of salinity, lowering water table to acceptable depths, and prevent future salinization.

The reclamation is not just an engineering project, the full reclamation are also may include, rural development, capacities building for operators and beneficiaries, educational development, research development, and social development.
\end{abstract}

Keywords: Land reclamation, Salinity, water logging, Iraq.

${ }^{1}$ Consultant Engineer, Baghdad, Iraq.

2 Consultant Engineer, Baghdad, Iraq. $\mathrm{m}$

${ }^{3}$ Lulea University of Technology, Sweden.

Article Info: Received: October 27, 2020. Revised: November 1, 2020.

Published online: November 15, 2020. 


\section{Introduction}

Iraq had adopted the reclamation of the irrigable lands since the mid of last century, the expansion trend at the beginning was horizontal. In addition, the reclamation at this stage was not precise nor accurate in term of technical aspects, where the most important goals from reclamation at the center and southern of Iraq is to confront the salinity and water logging. Therefore, problems aggravated vertically and horizontally.

This policy has changed radically after the seventies of the last century by following scientific trends in the implementation of irrigation and reclamation projects of lands, in order to preserve water resources and organize water use up to the field level to ensure the treatment and prevention of salinity and water logging problems. On another hand, reclamation had a key role to increase agricultural density, diversification of agricultural cycles, using advanced technology and activating scientific research activities in these topics, taking into account the strategic importance of the issue of food security in Iraq.

\section{The evolution of the stages of land reclamation in Iraq}

It can be said that the term land reclamation was not known in its scientific content in Iraq until the end of the first half of the last century, and it was not coincided with the horizontal expansion in irrigation of lands when the first plan for irrigation projects in Iraq was drawn up by Development Board at the beginning of the fifties of the last century. It is common that the irrigation project was for a simple reason, which is that most of the projects that were planned at that time were based on one aspect of the project, which is the irrigation activity only, and even this aspect did not consider integration. It was just to improve the old networks and in all cases was low intensity or semi - intensive agriculture as a system of agricultural exploitation in line with the reality of ownership patterns that were prevailing during that era (Directorate General of Irrigation, 1954).

The concept of land reclamation has evolved in the sixties by the application of the Law of Agrarian Reform No (30) in the year 1958 , which has led to an increasing rate of salinity and rising groundwater levels. This situation argued decision makers to find and urgent solution, which is the adoption and implementation of the drains. Plans to implement drainage networks were adopted in the 1960s and the term drainage became conjugated with the concept of reclamation, and in most cases the drainage process became understood as a process called reclamation. However, the implementation of the drainage networks, which was initially limited to the main drains and then expanded to the branch drains and then the combined drains, was not actually a real reclamation process, because the main goal of its implementation was to reduce groundwater levels to the level that the density of the drainage networks allowed. The problem of salinity accumulated in productive soil layers and increasing as a result of irrigation, was still existing (Kanaan Abduljabar AbuGullal, 2019; Dieleman and Roumans, 1963). 
In spite of some limited benefits due to conducting drainage in this way, the concept of reclamation as an integrated process in terms of study, design and implementation did not take its true status until several years later. Where installation of field drains, field irrigation, land levelling, leaching, and planting became and essential parts of the reclamation .

The concept of land reclamation in Iraq has expanded, going beyond the technical and economic aspects to the integrated development concept, with planning, study, design and implementation, and this concept was clearly adopted in the five-year plan (1981-1985), the reclamation projects that were approved and entered the implementation phase included the establishment integrated road networks in the project, during the implementation phase of the reclamation work, provided that electricity and drinking water networks, housing projects, schools, clinics and other service facilities were established, so that the project can be developed in an integrated manner and create a new, developed cultural reality in economic and social conditions (Kanaan Abduljabar Abu-Gullal, 2019; MoWR 2005; Al-Simawi, 2010).

\section{Technical and economic basis for the reclamation of lands}

The land reclamation projects are among the development projects that are costly in terms of the capital investment, and their implementation takes a long time, in which various complex activities overlapped .

Such projects can only be accomplished by the state authorities, by allocating huge sums in its developmental investments, and by mobilizing large operational resources. Therefore, projects that had the form of public benefit and have major implications for the agricultural development and the national economy, because the problem of salts spread and waterlogging in agricultural lands is one of the most important obstacles for the development of agriculture sector in Iraq and has negative economic and social consequences. (Kanaan Abduljabar Abu-Gullal, 2019; JICA, 1977). The programs of land reclamation are aiming to:

1. Maintaining soil fertility and productivity at its planned levels (preservative reclamation).

2. Restoring soil fertility to its previous levels before soil salinization and waterlogging.

3. Development of agricultural production elements, especially the irrigation network, levelling and aeration of the soil, which is meaning that land reclamation aims to develop agricultural production vertically by raising the production rates of the unit of land, and by extension to the lands involved in agricultural exploitation. 
Especially those lands that went out of production due to salinity.

As the lands of most of the irrigation projects in the central and southern Iraq are affected by salinization and waterlogging, a number of economic and technical criteria have been set to determine the priority in choosing land reclamation projects. The most important of them are the following:

1. Availability of water quantities for the cultivation of the lands with an agricultural density of not less than $120 \%$.

2. Availability of lands with high productivity according to soil studies and investigations.

3. Availability of population density to provide manpower to exploit the lands after completing its reclamation.

4. The proximity of projects to marketing and service centers and urban areas.

5. Focusing on completing direct projects that have reached the stage of investment and exploitation, with priority given to important strategic projects.

6. The project is related to the overall land and water development plan.

7. Geographical distribution of projects along Iraq in line with the principle of the development budget.

8. Adopting technical and economic analysis to give priority of implementing reclamation works in the existing projects to rehabilitate them after evaluation or to select new projects and on the basis of what these projects achieve in terms of added value to income in addition to other economic and social goals.

9. Adopting the principle of integrated reclamation for projects, where reclamation works include developing the irrigation network and implementing drainage networks, starting from field drains and ending with main drains, leveling, soil leaching and land planting.

\section{Stages of reclamation process}

The most important goal of the land reclamation process in the status of the central and southern Iraq ( the Mesopotamian plain in particular) is to get rid the soil salinity in its productive layers that makes plant growth impossible or with diminishing and uneconomic yields, to preserve groundwater levels at non-critical depths, and prevent its negative impact on the growth of agricultural crops and this is done by finding an appropriate saline and water balance that can be obtained as a result of implementing integrated networks of irrigation and drainage and manipulating the topographic levels by modifying and leveling lands and the subsequent work of washing and cultivating the lands (Kanaan Abduljabar Abu-Gullal, 2019; AlSimawi, 2010). The process of land reclamation takes place in several basic stages, which are in brief: 


\subsection{Studies and designs stage}

This includes conducting a topographical survey, soil survey, land classification, hydrological investigations for the project, and the use of geological, climatic and morphological information for the area, and studying the social situation and agricultural and economic activity existing in it for the purpose of outlining the conditions and factors that affecting the reclamation process. Furthermore, to reach an assessment in the first stage of the study leads in the case of feasibility to the development of economic and social justification for the implementation of the project and then move on to the stage of the preparation of maps and detailed design of irrigation and drainage and structures.

Usually, studies focus on basic problems which are the salinity and high water levels of groundwater, so it's required at this stage study these two problems are given in the most detail as possible and the information can be used to address them in terms of design (Kanaan Abduljabar; Abu-Gullal, Al-Athari, and Abu-Gullal, 2017). This stage ends when preparing designs, specifications, contracting documents, O\&M manuals for the project, where the project is referred for implementation.

\subsection{Implementation stage}

Reclamation project includes the implementation of several items, of which the most important:

1. Irrigation network: It includes the main canal, branch canal, distributary and feeding channels, its structures, and pumping stations, if any in the design. Since the mid-seventies, the lining of the entire irrigation network from the main canal to the feeding channels has become a prevailing principle in all projects, where the concrete was mostly used as a material for lining.

2. Drainage network: It includes the main, branch, collector and field drains that all form the drainage network of the reclaimed project, where drainage water is discharged into the main outfall drain or into rivers in special cases or into natural depressions.

3. Land levelling: The aim of this process is to remove the differences in elevations topography .

4. Leaching and planting stage: This stage is one of the most important stages of the reclamation process in the circumstances of Iraq, as the process of soil leaching is linked to the main problem that afflicts the soils of central and southern Iraq, which is the problem of salinity accumulated at high rates in the productive soil layers. After the implementation of integrated networks for irrigation and drainage, it becomes possible to conduct this process. The leaching and planting operations are carried out according to the established technical specifications. The saline concentration is the main factor in determining the areas that need to be leached, as well as the areas that can be cultivated or to determine the types of crops that can be grown. 
5. Hand over the reclaimed lands to the beneficiaries: Reclaimed lands are handed over to the beneficiaries in accordance with the laws, decisions and instructions arranged in this regard and through committees in which the designing implementing and beneficiaries are represented.The beneficiaries receive maps and information related to the project or part of it (Kanaan Abduljabar; Abu-Gullal, Al-Athari, and Abu-Gullal 2017; Allen et al. 1998).

\section{The future prospects for land reclamation in Iraq}

Future prospects of reclamation in Iraq might base on the following indicators:

1. Considering the reclamation project as the basis for developing the project area, and focusing the rest of the sectors on it in order to secure all the requirements for the success of the project's objectives economic and social goals.

2. Developing and implementing a plan to educate farmers in cooperation with agricultural and youth unions, organizations, and relevant authorities in the agricultural sector to make them aware of the methods of project operation and maintenance .

3. Focusing in particular on the operation and maintenance of the reclaimed projects as it is the most important project in terms of integration of implementation.

4. Reactivate MEAL activities annually and periodically, as well as to the overall activities for the purpose of benefiting them in the face of potential problems or avoid them, especially with regard to the salinity of the soil and the problem of re-salinization as the land reclaimed threatened to re-salinization as a result of mismanagement and cultivation and not to give serious importance to the proper O\&M.

\section{Recent status of reclamation projects in Iraq}

According to the last updates by Ministry of Water Resources (MoWR), there are 142 irrigation projects (reclaimed, partially reclaimed, and non-reclaimed), there are as well 275 pumping stations. Figure 1 below shows irrigation projects map in Iraq.

According to the report published by (JICA agency), there are about $16 \%$ or 7 million ha of area are arable land, of which about 5.985million ha is under irrigation or rain-fed. From this area, about $64 \%$ of cultivated land is irrigated, of which 3.384 million ha is irrigated by surface, while the rain-fed area is about 2.175 million ha. Regarding cropping ratio, and according to the information of the year 2011, the ratio was $70 \%$. In 2011 , due to the drought, cropping ratio decreased by about $20 \%$. While the average cropping ratio was estimated about $85 \%$, this estimation made according to SWLRI study, which is Strategy of Water and Land Resources in Iraq (JICA, 2016). 


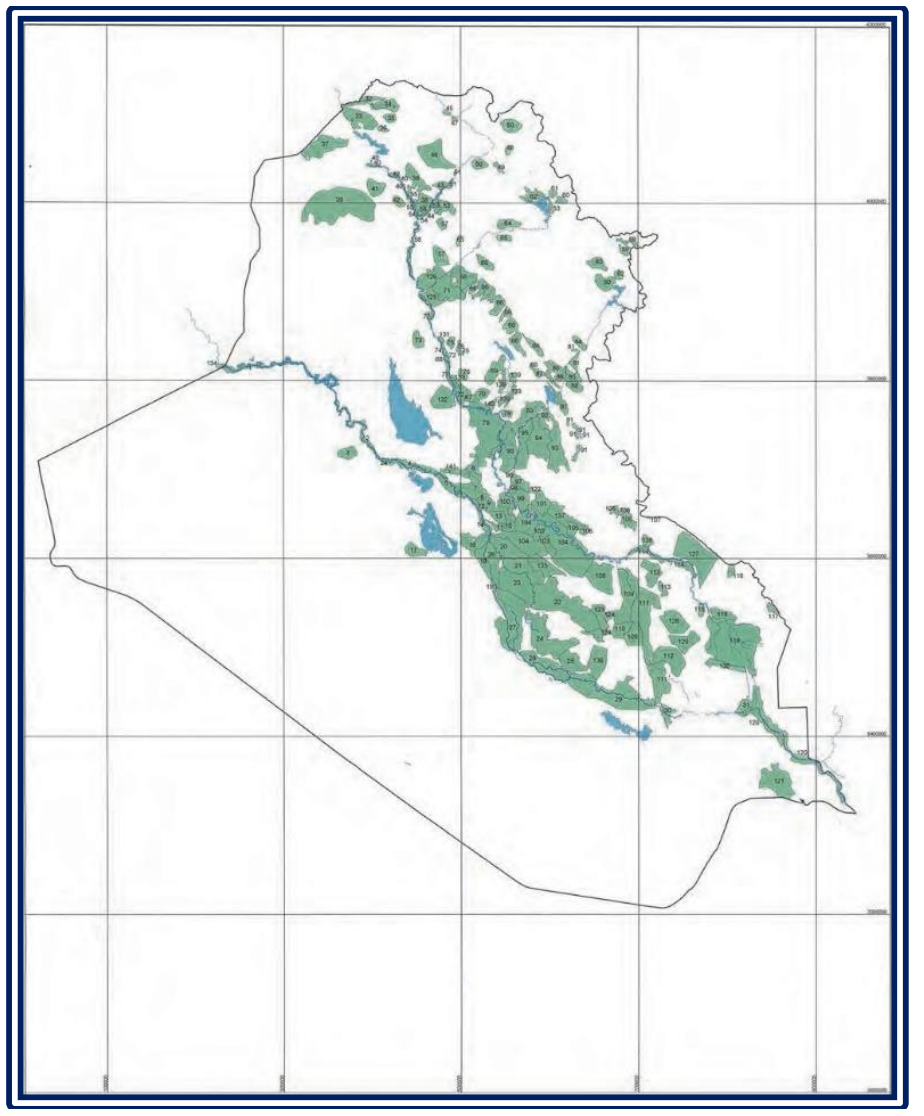

Figure 1: Irrigation projects in Iraq. (JICA 2016). Through SWLRI study, an evaluation was made to the recent status of canals. As shown in Table 1, there are approximately $20-24 \%$ of these canals with concrete lining.

Table 1: Length and Lining Ratio of Main, Branch and Secondary Canals (JICA 2016).

\begin{tabular}{|l|c|c|c|c|c|c|c|c|c|}
\hline & \multicolumn{3}{|c|}{ Main canals } & \multicolumn{3}{c|}{ Branch canals } & \multicolumn{3}{c|}{ Secondary canals } \\
\cline { 2 - 10 } & Lining & $\begin{array}{c}\text { Earth } \\
\text { canal }\end{array}$ & Other & Lining & $\begin{array}{c}\text { Earth } \\
\text { canal }\end{array}$ & Other & Lining & $\begin{array}{c}\text { Earth } \\
\text { canal }\end{array}$ & Other \\
\hline Length(km) & 1,972 & 7,729 & 26 & 2,332 & 9,330 & 254 & 2,353 & 6,018 & 1,493 \\
\hline Ratio (\%) & 20 & 79 & 1 & 20 & 78 & 2 & 24 & 61 & 15 \\
\hline
\end{tabular}


As seen in the above table, the low ratio of lining is one of drawbacks in the irrigation projects.

Table 2 shows the details of all 142 irrigation projects in Iraq These projects are covering an area of about 13.7 million donum. Data source for these details are from SWLRI study, which were listed in the reports of JICA agency. The tables also show the targeted development until the year 2035 according to SWLRI. Also, at the last rows, details can be found about each project water demands (JICA 2016; AlSimawi, 2008). 
Table 2: Details of Irrigation Projects in Iraq (JICA 2016)

\begin{tabular}{|c|c|c|c|c|c|c|c|c|c|c|c|c|c|c|}
\hline ID & $\begin{array}{l}\text { PROJECT } \\
\text { NAME }\end{array}$ & GOVERNORATE & SOURCE & RANKING & $\begin{array}{c}\text { Total } \\
\text { Area } \\
\text { MoWR } \\
\end{array}$ & $\begin{array}{l}\text { Develed } \\
\text { till } 2013\end{array}$ & $\begin{array}{c}\text { To Be } \\
\text { Developed } \\
\text { in the Plan } \\
\end{array}$ & $\begin{array}{c}\text { Final } \\
\text { Development }\end{array}$ & $\begin{array}{c}\text { Net } \\
\text { area }\end{array}$ & $\begin{array}{c}\% \\
\text { DEV }\end{array}$ & $\begin{array}{c}\text { TOTAL } \\
\text { DEMAND }\end{array}$ & $\begin{array}{c}\text { Total } \\
\text { dem/kdon }\end{array}$ & $\begin{array}{c}\text { Max } \\
\text { Monthly } \\
\text { demand }\end{array}$ & $\begin{array}{c}\text { Max } \\
\text { discharge } \\
(1 / \mathbf{s}) \\
\end{array}$ \\
\hline 1 & $\begin{array}{l}\text { Small farms } \\
\text { to hadeetha } \\
\text { dam }\end{array}$ & Anbar & Euphrates & 71 & 59 & 4 & 47.3 & 51.3 & 45.0 & $87 \%$ & 130.3 & 2895.556 & 21.5 & 8.29 \\
\hline 2 & $\begin{array}{l}\text { Small farms } \\
\text { from the } \\
\text { hadeetha } \\
\text { dam }\end{array}$ & Anbar & Euphrates & 81 & 47 & 1 & 46 & 47 & 41.2 & $100 \%$ & 132.5 & 3213.83 & 21 & 8.10 \\
\hline 3 & $\begin{array}{l}\text { Up to the } \\
\text { boundary of } \\
\text { the Ramadi } \\
\text { project } \\
\text { Small farms } \\
\text { at springs in } \\
\text { the Anbar }\end{array}$ & Anbar & $\begin{array}{l}\text { GW- } \\
\text { springs }\end{array}$ & GW & 1 & & 1 & 1 & 0.9 & $100 \%$ & 2.9 & 3306 & 0.5 & 0.19 \\
\hline 4 & $\begin{array}{l}\text { Ramadi- } \\
\text { habaniyah }\end{array}$ & Anbar & Euphrates & 73 & 135 & 111 & 20.4 & 131.4 & 115.3 & $97 \%$ & 326.8 & 2835.251 & 52.1 & 20.10 \\
\hline 5 & $\begin{array}{l}\text { Faluja- } \\
\text { amreah }\end{array}$ & AnbarBaghdad & Euphrates & 75 & 56 & & 50.4 & 50.4 & 44.2 & $90 \%$ & 134 & 3030.952 & 21.6 & 8.33 \\
\hline 6 & Saqlawiya & Anbar-Baghdad & Euphrates & $\mathrm{D}$ & 140 & 140 & 0 & 140 & 122.8 & $100 \%$ & 367.7 & 2994.129 & 60 & 23.15 \\
\hline 7 & Abu ghraib & Anbar-Baghdad & Euphrates & $\mathrm{D}$ & 206 & 206 & 0 & 206 & 180.7 & $100 \%$ & 576.8 & 3192 & 93 & 35.88 \\
\hline 8 & Radhwaniyah & Baghdad & Euphrates & $\mathrm{D}$ & 28 & 28 & 0 & 28 & 24.6 & $100 \%$ & 81 & 3297.857 & 13 & 5.02 \\
\hline 9 & Yousifia & Baghdad-Wasit & Euphrates & 45 & 125 & 57 & 68 & 125 & 109.6 & $100 \%$ & 360 & 3283.2 & 57.8 & 22.30 \\
\hline 10 & Latifia & Baghdad-Babil & Euphrates & 37 & 108 & 88 & 20 & 108 & 94.7 & $100 \%$ & 304.8 & 3217.333 & 48.8 & 18.83 \\
\hline 11 & Iskandariyah & Baghdad-Babil & Euphrates & 42 & 51 & 44 & 0 & 44 & 38.6 & $86 \%$ & 122.3 & 3168.682 & 19.5 & 7.52 \\
\hline 12 & $\begin{array}{l}\text { Faluja al- } \\
\text { muahada }\end{array}$ & $\begin{array}{l}\text { Anbar-Baghdad } \\
\text { Babil }\end{array}$ & Euphrates & 62 & 54 & & 54 & 54 & 47.4 & $100 \%$ & 152.2 & 3213.111 & 24.4 & 9.41 \\
\hline 13 & $\begin{array}{l}\text { Small farms } \\
\text { from the } \\
\text { boundary of } \\
\text { the anbar } \\
\text { muhafadha }\end{array}$ & Babil & Euphrates & 72 & 25 & & 15 & 15 & 13.2 & $60 \%$ & 42.4 & 3222.4 & 6.8 & 2.62 \\
\hline 14 & $\begin{array}{l}\text { Jarf al sakhr } \\
\text { \& ruwaiyah }\end{array}$ & $\begin{array}{l}\text { Anbar-Baghdad } \\
\text { Babil-Karbala }\end{array}$ & Euphrates & 69 & 38 & & 38 & 38 & 33.3 & $100 \%$ & 107.8 & 3234 & 17.2 & 6.64 \\
\hline
\end{tabular}


Abu-Gullal et al.

\begin{tabular}{|c|c|c|c|c|c|c|c|c|c|c|c|c|c|c|}
\hline 15 & $\begin{array}{l}\text { Greater } \\
\text { musaiyab }\end{array}$ & Babil & Euphrates & $\mathrm{D}$ & 310 & 310 & 0 & 310 & 271.9 & $100 \%$ & 836.1 & 3074.69 & 132.5 & 51.12 \\
\hline 16 & Husainaia & Babil-Karbala & Euphrates & 41 & 101 & 80 & 21 & 101 & 88.6 & $100 \%$ & 251.9 & 2843.228 & 36.9 & 14.24 \\
\hline 17 & $\begin{array}{l}\text { Small farms; } \\
\text { at spring } \\
\text { irrigated in } \\
\text { karbala }\end{array}$ & Anbar-Karbala & $\begin{array}{l}\text { GW } \\
\text { springs }\end{array}$ & GW & 10 & 10 & 0 & 10 & 8.8 & $100 \%$ & 29.7 & 3385.8 & 4.9 & 1.89 \\
\hline 18 & Bani-hasan & $\begin{array}{l}\text { Babil-Karbala } \\
\text { Najaf }\end{array}$ & Euphrates & 52 & 145 & 43 & 81.6 & 124.6 & 109.3 & $86 \%$ & 304.7 & 2787.785 & 44.3 & 17.09 \\
\hline 19 & $\begin{array}{l}\text { Small farms } \\
\text { from the } \\
\text { Hindiyah } \\
\text { barrage }\end{array}$ & $\begin{array}{l}\text { Babil-Karbala } \\
\text { Najaf }\end{array}$ & Euphrates & 64 & 4 & & 3.6 & 3.6 & 3.2 & $90 \%$ & 8.7 & 2755 & 1.3 & 0.50 \\
\hline 20 & $\begin{array}{l}\text { Iskandariyah } \\
\text {-mehaweel } \\
\text { \& gadwel al- } \\
\text { nasiriya } \\
\end{array}$ & Babil & Euphrates & 74 & 182 & 11 & 153.3 & 164.3 & 144.1 & $90 \%$ & 432.7 & 3002.301 & 68.7 & 26.50 \\
\hline 21 & $\begin{array}{l}\text { Hilla- } \\
\text { hashimiyah }\end{array}$ & Babil & Euphrates & 70 & 240 & & 204 & 204 & 178.9 & $85 \%$ & 531.2 & 2968.471 & 84.2 & 32.48 \\
\hline 22 & $\begin{array}{l}\text { Huriyah- } \\
\text { daghara }\end{array}$ & Babil-Diwaniyah & Euphrates & 12 & 635 & 207 & 428 & 635 & 557.0 & $100 \%$ & $1,702.50$ & 3056.457 & 243.1 & 93.79 \\
\hline 23 & $\begin{array}{l}\text { Hilla- } \\
\text { diwaniyah }\end{array}$ & $\begin{array}{l}\text { Babil-Diwaniyah } \\
\text { Najaf }\end{array}$ & Euphrates & 55 & 282 & & 273.8 & 273.8 & 240.2 & $97 \%$ & 643.6 & 2679.708 & 100 & 38.58 \\
\hline 24 & $\begin{array}{l}\text { Diwaniyah- } \\
\text { shaifiyah }\end{array}$ & $\begin{array}{l}\text { Diwaniyah } \\
\text { Muthanna }\end{array}$ & Euphrates & 19 & 380 & & 380 & 380 & 333.3 & $100 \%$ & $1,031.90$ & 3095.7 & 157.7 & 60.84 \\
\hline 25 & Rumaitha & Muthanna & Euphrates & 40 & 144 & 30 & 114 & 144 & 126.3 & $100 \%$ & 426.6 & 3377.25 & 58.4 & 22.53 \\
\hline 26 & Hilla-kifil & $\begin{array}{l}\text { Babil-Karbala } \\
\text { Najaf }\end{array}$ & Euphrates & $\mathrm{D}$ & 173 & 173 & 0 & 173 & 151.8 & $100 \%$ & 411.5 & 2711.618 & 59.7 & 23.03 \\
\hline 27 & $\begin{array}{l}\text { Kifil- } \\
\text { shnafiyah }\end{array}$ & $\begin{array}{l}\text { Babil-Diwaniyah } \\
\text { Najaf }\end{array}$ & Euphrates & 58 & 494 & 50 & 444 & 494 & 433.3 & $100 \%$ & $1,338.00$ & 3087.692 & 192.4 & 74.23 \\
\hline 28 & Muthanna & Muthanna & Euphrates & 27 & 41 & 32 & 9 & 41 & 36.0 & $100 \%$ & 123 & 3420 & 18.7 & 7.21 \\
\hline
\end{tabular}




\begin{tabular}{|c|c|c|c|c|c|c|c|c|c|c|c|c|c|c|}
\hline 29 & $\begin{array}{l}\text { Shnafiyah- } \\
\text { nasiriya }\end{array}$ & $\begin{array}{l}\text { Diwaniyah/Dhi- } \\
\text { Qar/Muthanna }\end{array}$ & Euphrates & 43 & 260 & & 260 & 260 & 228.1 & $100 \%$ & 790.8 & 3467.354 & 118.9 & 45.87 \\
\hline 30 & $\begin{array}{l}\begin{array}{l}\text { Suq al } \\
\text { shoyokh }\end{array} \\
\end{array}$ & Dhi-Qar & Euphrates & 65 & 75 & & 22.5 & 22.5 & 19.7 & $30 \%$ & 72 & 3648 & 10.4 & 4.01 \\
\hline 31 & $\begin{array}{l}\text { Small farms } \\
\text { in the } \\
\text { Euphrates } \\
\text { river mouth }\end{array}$ & Basrah & Tigris & 53 & 35 & & 35 & 35 & 30.7 & $100 \%$ & 93.1 & 3032.4 & 16.2 & 6.25 \\
\hline 32 & Zakho & Dohuk & GW-wells & 60 & 15 & & 15 & 15 & 13.2 & $100 \%$ & 17.3 & 1314.8 & 4 & 1.54 \\
\hline 33 & $\begin{array}{l}\text { Small farms } \\
\text { from the } \\
\text { boundary } \\
\text { up to Mosul } \\
\text { dam }\end{array}$ & Dohuk/Nineveh & Tigris & 63 & 11 & & 11 & 11 & 9.6 & $100 \%$ & 14.6 & 1513.091 & 3.2 & 1.23 \\
\hline 34 & $\begin{array}{l}\text { Small farms } \\
\text { at springs in } \\
\text { the dohuk }\end{array}$ & Dohuk & GW-springs & GW & 4 & & 4 & 4 & 3.5 & $100 \%$ & 5.7 & 1624.5 & 1.4 & 0.54 \\
\hline 35 & $\begin{array}{l}\text { Small farms } \\
\text { at wells in } \\
\text { the }\end{array}$ & Dohuk & GW-wells & GW & 1 & & 1 & 1 & 0.9 & $100 \%$ & 1.4 & 1596 & 0.4 & 0.15 \\
\hline 36 & Dohuk & Dohuk & Tigris & $\mathrm{D}$ & 2 & 2 & 0 & 2 & 1.8 & $100 \%$ & 2.6 & 1482 & 0.6 & 0.23 \\
\hline 37 & $\begin{array}{l}\text { North } \\
\text { jazeera }\end{array}$ & Nineveh & Tigris & $\mathrm{D}$ & 264 & 264 & 0 & 264 & 231.6 & $100 \%$ & 477.6 & 2062.364 & 98.8 & 38.12 \\
\hline 38 & East jazeera & Nineveh & Tigris & 26 & 215 & 12 & 203 & 215 & 188.6 & $100 \%$ & 403 & 2136.837 & 90.3 & 34.84 \\
\hline 39 & $\begin{array}{l}\text { South } \\
\text { jazeera }\end{array}$ & Nineveh & Tigris & 8 & 344 & & 344 & 344 & 301.8 & $100 \%$ & 670.3 & 2221.343 & 118.6 & 45.76 \\
\hline 40 & $\begin{array}{l}\text { Small farms } \\
\text { up to } \\
\text { greater zab } \\
\text { river }\end{array}$ & Nineveh & Tigris & 33 & 46 & & 46 & 46 & 40.4 & $100 \%$ & 86.1 & 2133.783 & 19.3 & 7.45 \\
\hline 41 & $\begin{array}{l}\text { Small farms } \\
\text { at springs in } \\
\text { the Ninawa }\end{array}$ & Nineveh & GW-springs & GW & 2 & & 2 & 2 & 1.8 & $100 \%$ & 3.6 & 2052 & 0.8 & 0.31 \\
\hline 42 & $\begin{array}{l}\text { Small farms } \\
\text { at wells in } \\
\text { the Ninawa }\end{array}$ & Nineveh & GW-wells & GW & 1 & & 1 & 1 & 0.9 & $100 \%$ & 2 & 2280 & 0.4 & 0.15 \\
\hline
\end{tabular}


Abu-Gullal et al.

\begin{tabular}{|c|c|c|c|c|c|c|c|c|c|c|c|c|c|c|}
\hline 43 & $\begin{array}{l}\text { Small farms } \\
\text { at springs in } \\
\text { the Ninawa }\end{array}$ & Nineveh & GW-springs & GW & 3 & & 3 & 3 & 2.6 & $100 \%$ & 5.3 & 2014 & 1 & 0.39 \\
\hline 44 & $\begin{array}{l}\text { Small farms } \\
\text { at wells in } \\
\text { the Ninawa }\end{array}$ & Nineveh & GW-wells & GW & 4 & & 4 & 4 & 3.5 & $100 \%$ & 7.4 & 2109 & 1.4 & 0.54 \\
\hline 45 & Balandah & Dohuk & Greater Zab * & 83 & 1 & & rainfed & & 0.0 & & & & & 0.00 \\
\hline 46 & $\begin{array}{l}\text { Khazir- } \\
\text { gomel }\end{array}$ & Nineveh & Khazir * & 61 & 148 & & rainfed & & 0.0 & & & & & 0.00 \\
\hline 47 & Bela-rizan & Dohuk/Nineveh & Greater Zab * & 80 & 1 & & rainfed & & 0.0 & & & & & 0.00 \\
\hline 48 & $\begin{array}{l}\text { Diyana- } \\
\text { balikiyan }\end{array}$ & Erbil & Greater Zab & 87 & 6 & & 0.9 & 0.9 & 0.8 & $15 \%$ & 1.5 & 1900 & 0.4 & 0.15 \\
\hline 49 & Harir & Erbil & Greater Zab * & 78 & 25 & & rainfed & & 0.0 & & & & & 0.00 \\
\hline 50 & $\begin{array}{l}\text { Small farms } \\
\text { at springs in } \\
\text { the erbil }\end{array}$ & Nineveh/Erbil & GW-springs & GW & 1 & & 1 & 1 & 0.9 & $100 \%$ & 1.7 & 1938 & 0.4 & 0.15 \\
\hline 51 & Markaz & Nineveh/Erbil & Greater Zab & 39 & 14 & & 5.6 & 5.6 & 4.9 & $40 \%$ & 10.2 & 2076.4 & 1.9 & 0.73 \\
\hline 52 & Shemamuk & Erbil & Greater Zab & 30 & 60 & & 54 & 54 & 47.4 & $90 \%$ & 101.4 & 2140.667 & 18.8 & 7.25 \\
\hline 53 & Eski-kalak & Nineveh/Erbil & Greater Zab & $\mathrm{D}$ & 42 & 42 & 0 & 42 & 36.8 & $100 \%$ & 81.4 & 2209.429 & 14.5 & 5.59 \\
\hline 54 & Kashaf & Nineveh/Erbil & Greater Zab & 14 & 12 & & 12 & 12 & 10.5 & $100 \%$ & 25.3 & 2403.5 & 4.6 & 1.77 \\
\hline 55 & Sallamiyah & Nineveh & Tigris & $\mathrm{D}$ & 9 & 9 & 0 & 9 & 7.9 & $100 \%$ & 17.2 & 2178.667 & 3.2 & 1.23 \\
\hline 56 & $\begin{array}{l}\text { Small farms } \\
\text { at wells in } \\
\text { the ninawa }\end{array}$ & Nineveh & GW-wells & GW & 1 & & 1 & 1 & 0.9 & $100 \%$ & 1.9 & 2166 & 0.4 & 0.15 \\
\hline 57 & Makhmur & Erbil/Kirkuk & Greater Zab * & 54 & 140 & & rainfed & & 0.0 & & & & & 0.00 \\
\hline 58 & $\begin{array}{l}\text { Small farms } \\
\text { at well in } \\
\text { the ninawa }\end{array}$ & $\begin{array}{l}\text { Nineveh/Salah- } \\
\text { ad-din }\end{array}$ & GW-wells & GW & 42 & & 42 & 42 & 36.8 & $100 \%$ & 107.6 & 2920.571 & 19.2 & 7.41 \\
\hline
\end{tabular}




\begin{tabular}{|c|c|c|c|c|c|c|c|c|c|c|c|c|c|c|}
\hline 59 & Penjween & Sulaymaniyah & Lesser Zab & 85 & 10 & & 10 & 10 & 8.8 & $100 \%$ & 16.3 & 1858.2 & 4.2 & 1.62 \\
\hline 60 & $\begin{array}{l}\text { Small farms at } \\
\text { siprins in the } \\
\text { sulaymaniyah }\end{array}$ & Sulaymaniyah & GW-springs & GW & 2 & & 2 & 2 & 1.8 & $100 \%$ & 3.6 & 2052 & 0.9 & 0.35 \\
\hline 61 & Sangasar & Sulaymaniyah & Lesser Zab & 25 & 2 & & 2 & 2 & 1.8 & $100 \%$ & 3.8 & 2166 & 0.9 & 0.35 \\
\hline 62 & $\begin{array}{l}\text { Raniya- } \\
\text { sarujawa }\end{array}$ & $\begin{array}{l}\text { Erbil/Sulaymaniya } \\
\text { h }\end{array}$ & Lesser Zab & 82 & 48 & 10 & 0 & 10 & 8.8 & $21 \%$ & 15.7 & 1789.8 & 3.4 & 1.31 \\
\hline 63 & Sarsiyan & Sulaymaniyah & Lesser Zab * & 79 & 1 & & rainfed & & 0.0 & & & & & 0.00 \\
\hline 64 & $\begin{array}{l}\text { Small farms at } \\
\text { springs in the } \\
\text { erbil }\end{array}$ & Erbil & GW-springs & GW & 1 & & 1 & 1 & 0.9 & $100 \%$ & 1.8 & 2052 & 0.4 & 0.15 \\
\hline 65 & $\begin{array}{l}\text { Small farms at } \\
\text { wells in the } \\
\text { kirkuk } \\
\text { muhafadha }\end{array}$ & Erbil/Kirkuk & GW-wells & GW & 1 & & 1 & 1 & 0.9 & $100 \%$ & 1.9 & 2166 & 0.4 & 0.15 \\
\hline 66 & Kirkuk & $\begin{array}{l}\text { Kirkuk } \\
\text { Salah-ad-din } \\
\text { Diyala }\end{array}$ & Lesser Zab & $\mathrm{D}$ & 662 & 662 & 0 & 662 & 580.7 & $100 \%$ & $1,298.40$ & 2235.915 & 224.7 & 86.69 \\
\hline 67 & $\begin{array}{l}\text { Resasy- } \\
\text { tereshiyah }\end{array}$ & Salah-ad-din & Tigris & 76 & 60 & & 60 & 60 & 52.6 & $100 \%$ & 135.9 & 2582.1 & 23.5 & 9.07 \\
\hline 68 & Al boajeel & Salah-ad-din & Tigris & $\mathrm{D}$ & 6 & 6 & 0 & 6 & 5.3 & $100 \%$ & 16.2 & 3078 & 2.8 & 1.08 \\
\hline 69 & $\begin{array}{l}\text { Small farms at } \\
\text { springs in the } \\
\text { salahad din }\end{array}$ & Salah-ad-din & GW-springs & GW & 20 & & 20 & 20 & 17.5 & $100 \%$ & 47.2 & 2690.4 & 8.3 & 3.20 \\
\hline 70 & $\begin{array}{l}\text { Small farms at } \\
\text { wells in the } \\
\text { salah addin }\end{array}$ & Salah-ad-din & GW-wells & GW & 16 & & 16 & 16 & 14.0 & $100 \%$ & 37.6 & 2679 & 6.5 & 2.51 \\
\hline 71 & Haweeja & Kirkuk & Lesser Zab & 23 & 192 & 100 & 92 & 192 & 168.4 & $100 \%$ & 398.7 & 2367.281 & 68.4 & 26.39 \\
\hline
\end{tabular}


Abu-Gullal et al.

\begin{tabular}{|c|c|c|c|c|c|c|c|c|c|c|c|c|c|c|}
\hline 72 & $\begin{array}{c}\text { Small farms } \\
\text { from lesser } \\
\text { zab river } \\
\text { up to } \\
\text { udhaim }\end{array}$ & Salah-ad-din & Tigris & 56 & 102 & 0 & 102 & 102 & 89.5 & $100 \%$ & 240.9 & 2692.412 & 41.6 & 16.05 \\
\hline 73 & $\begin{array}{l}\text { Small farms at } \\
\text { wells in the } \\
\text { salah ad din }\end{array}$ & Salah-ad-din & GW-wells & $\mathrm{GW}$ & 7 & & 7 & 7 & 6.1 & $100 \%$ & 15.2 & 2475.429 & 2.5 & 0.96 \\
\hline 74 & $\begin{array}{l}\text { Al-khalij, al } \\
\text { aali }\end{array}$ & Salah-ad-din & Tigris & $\mathrm{D}$ & 18 & 18 & 0 & 18 & 15.8 & $100 \%$ & 47 & 2976.667 & 8.1 & 3.13 \\
\hline 75 & Upper naifah & Salah-ad-din & Tigris & 48 & 59 & & 59 & 59 & 51.8 & $100 \%$ & 150.3 & 2904.102 & 25.8 & 9.95 \\
\hline 76 & Dour & Salah-ad-din & Tigris & $\mathrm{D}$ & 8 & 8 & 0 & 8 & 7.0 & $100 \%$ & 20.4 & 2907 & 3.5 & 1.35 \\
\hline 77 & $\begin{array}{l}\text { Al-aoja \& } \\
\text { dujail }\end{array}$ & Salah-ad-din & Tigris & $\mathrm{D}$ & 24 & 24 & 0 & 24 & 21.1 & $100 \%$ & 63.4 & 3011.5 & 10.9 & 4.21 \\
\hline 78 & Al-nai & $\begin{array}{l}\text { Salah-ad-din } \\
\text { Diyala }\end{array}$ & Tigris & $\mathrm{D}$ & 33 & 33 & 0 & 33 & 28.9 & $100 \%$ & 69.5 & 2400.909 & 11.2 & 4.32 \\
\hline 79 & Ishaqi & $\begin{array}{l}\text { Salah-addin } \\
\text { Baghdad }\end{array}$ & Tigris & $\mathrm{D}$ & 317 & 317 & 0 & 317 & 278.1 & $100 \%$ & 753.7 & 2710.467 & 127.6 & 49.23 \\
\hline 80 & Shahrazoor & Sulaymaniyah & Diyala * & 84 & 74 & & rainfed & & 0.0 & & & & & 0.00 \\
\hline 81 & Kalar & Sulaymaniyah & Diyala & 57 & 12 & 4 & 0 & 4 & 3.5 & $33 \%$ & 8.6 & 2451 & 1.9 & 0.73 \\
\hline 82 & Kaolas & Sulaymaniyah & Diyala * & 86 & 17 & & rainfed & & 0.0 & & & \#DIV/0! & & 0.00 \\
\hline 83 & $\begin{array}{l}\text { Small farms at } \\
\text { springs in the } \\
\text { sulaymaniyah }\end{array}$ & Sulaymaniyah & GW-springs & GW & 1 & & 1 & 1 & 0.9 & $100 \%$ & 1.6 & 1824 & 0.4 & 0.15 \\
\hline
\end{tabular}




\begin{tabular}{|c|c|c|c|c|c|c|c|c|c|c|c|c|c|c|}
\hline 84 & Shekh-langar & Sulaymaniyah & Diyala & 67 & 1 & & 1 & 1 & 0.9 & $100 \%$ & 2.1 & 2394 & 0.5 & 0.19 \\
\hline 85 & $\begin{array}{l}\text { Balajo- } \\
\text { khanaqeen- } \\
\text { wind }\end{array}$ & $\begin{array}{l}\text { Sulaymaniyah } \\
\text { Diyala }\end{array}$ & Diyala & 68 & 89 & & 89 & 89 & 78.1 & $100 \%$ & 167.1 & 2140.382 & 29.9 & 11.54 \\
\hline 86 & Qara teppe & Diyala & Diyala & 17 & 62 & & 62 & 62 & 54.4 & $100 \%$ & 117.2 & 2154.968 & 20 & 7.72 \\
\hline 87 & $\begin{array}{c}\text { Jalawlaa } \\
\& \\
\text { al-sa'diyah }\end{array}$ & Diyala & Diyala & 18 & 24 & & 24 & 24 & 21.1 & $100 \%$ & 47.7 & 2265.75 & 8 & 3.09 \\
\hline 88 & $\begin{array}{l}\text { Small farms at } \\
\text { wells in the } \\
\text { diyala }\end{array}$ & Diyala & GW-wells & GW & 4 & & 4 & 4 & 3.5 & $100 \%$ & 7.6 & 2166 & 1.3 & 0.50 \\
\hline 89 & Upper khalis & $\begin{array}{l}\text { Salah-ad-din } \\
\text { Diyala }\end{array}$ & Diyala & $\mathrm{D}$ & 216 & 216 & 0 & 216 & 189.5 & $100 \%$ & 467.1 & 2465.25 & 74.9 & 28.90 \\
\hline 90 & Lower khalis & $\begin{array}{l}\text { Diyala } \\
\text { Baghdad }\end{array}$ & Tigris & $\mathrm{D}$ & 230 & 230 & 0 & 230 & 201.8 & $100 \%$ & 587.7 & 2912.948 & 98.8 & 38.12 \\
\hline 91 & Mandeli & Diyala & Diyala & 13 & 29 & 3 & 26 & 29 & 25.4 & $100 \%$ & 64.9 & 2551.241 & 10.1 & 3.90 \\
\hline
\end{tabular}




\begin{tabular}{|c|c|c|c|c|c|c|c|c|c|c|c|c|c|c|}
\hline 92 & $\begin{array}{l}\text { Haruniyay+co } \\
\text { mbined head } \\
\text { reach } \\
\text { (sudour)+ } \\
\text { muqdadiyah }\end{array}$ & Diyala & Diyala & $\mathrm{D}$ & 93 & 85 & 8 & 93 & 81.6 & $100 \%$ & 188.1 & 2305.742 & 28.7 & 11.07 \\
\hline 93 & Ruz & Diyala & Diyala & $\mathrm{D}$ & 230 & 230 & 0 & 230 & 201.8 & $100 \%$ & 541.7 & 2684.948 & 82.6 & 31.87 \\
\hline 94 & Mahrut & Diyala & Diyala & 38 & 190 & 10 & 100 & 110 & 96.5 & $58 \%$ & 283.1 & 2933.945 & 48.1 & 18.56 \\
\hline 95 & $\begin{array}{l}\text { Khoraisan } \\
\text { (sareah) + tel } \\
\text { asmar }\end{array}$ & Diyala/Baghdad & Diyala & 31 & 93.4 & & 93.4 & 93.4 & 81.9 & $100 \%$ & 238.8 & 2914.69 & 40.3 & 15.55 \\
\hline 96 & $\begin{array}{l}\text { Small farms in } \\
\text { the low course } \\
\text { of } \\
\text { diyala river }\end{array}$ & Baghdad & Diyala & 47 & 3 & & 3 & 3 & 2.6 & $100 \%$ & 7.4 & 2812 & 1.2 & 0.46 \\
\hline 97 & $\begin{array}{l}\text { 9th april } \\
\text { project } \\
\text { (nehrawan) } \\
\text { "previously } \\
\text { 7th of april } \\
\text { project" }\end{array}$ & Baghdad & Diyala & $\mathrm{D}$ & 78 & 78 & 0 & 78 & 68.4 & $100 \%$ & 227.1 & 3319.154 & 37.4 & 14.43 \\
\hline 98 & $\begin{array}{l}\text { Small farms } \\
\text { on left bank } \\
\text { of the diyala }\end{array}$ & Baghdad & Tigris & 51 & 17 & 0 & 12.8 & 12.8 & 11.2 & $75 \%$ & 37.1 & 3304.219 & 6 & 2.31 \\
\hline 99 & $\begin{array}{l}\text { Wihda } \\
\text { (nehrawan) }\end{array}$ & Baghdad/Wasit & Tigris & $\mathrm{D}$ & 85 & 85 & 0 & 85 & 74.6 & $100 \%$ & 251.5 & 3373.059 & 40.8 & 15.74 \\
\hline 100 & Hour-rijab & Baghdad/Wasit & Tigris & $\mathrm{D}$ & 95 & 95 & 0 & 95 & 83.3 & $100 \%$ & 275.9 & 3310.8 & 44.4 & 17.13 \\
\hline 101 & $\begin{array}{l}\text { Suwairah } \\
\text { (hafria) }\end{array}$ & $\begin{array}{l}\text { Diyala/Baghdad } \\
\text { Wasit }\end{array}$ & Tigris & $\mathrm{D}$ & 148 & 148 & 0 & 148 & 129.8 & $100 \%$ & 398.9 & 3072.608 & 59.3 & 22.88 \\
\hline 102 & Qusaiba & Wasit/Babil & Tigris & $\mathrm{D}$ & 55 & 55 & 0 & 55 & 48.2 & $100 \%$ & 141.1 & 2924.618 & 20.5 & 7.91 \\
\hline 103 & Shihaimiyah & Wasit/Babil & Tigris & $\mathrm{D}$ & 72 & 72 & 0 & 72 & 63.2 & $100 \%$ & 185.7 & 2940.25 & 25.9 & 9.99 \\
\hline
\end{tabular}




\begin{tabular}{|c|c|c|c|c|c|c|c|c|c|c|c|c|c|c|}
\hline 104 & Middle tigris & $\begin{array}{l}\text { Baghdad/Wasit } \\
\text { Babil/Diwaniyah }\end{array}$ & Tigris & 35 & 528.2 & & 528.2 & 528.2 & 463.3 & $100 \%$ & $1,442.50$ & 3113.309 & 196.6 & 75.85 \\
\hline 105 & $\begin{array}{l}\text { Daboni } \\
\text { (al-jutfarms) }\end{array}$ & Wasit & Tigris & $\mathrm{D}$ & 68 & 68 & 0 & 68 & 59.6 & $100 \%$ & 196.5 & 3294.265 & 27 & 10.42 \\
\hline 106 & Badra-jassan & Wasit & Tigris & 21 & 75 & 47 & 28 & 75 & 65.8 & $100 \%$ & 198.3 & 3014.16 & 30.3 & 11.69 \\
\hline 107 & Karmashiyah & Wasit & $\begin{array}{l}\text { Eastern } \\
\text { Tributaries }\end{array}$ & 77 & 1 & & 1 & 1 & 0.9 & $100 \%$ & 2.6 & 2964 & 0.4 & 0.15 \\
\hline 108 & Dalmaj & Wasit & Tigris & $\mathrm{D}$ & 296 & 296 & 0 & 296 & 259.6 & $100 \%$ & 848.9 & 3269.412 & 114.5 & 44.17 \\
\hline 109 & West gharaf & Wasit/Dhi-Qar & Tigris & 15 & 337 & 60 & 277 & 337 & 295.6 & $100 \%$ & 999.3 & 3380.421 & 138.6 & 53.47 \\
\hline 110 & $\begin{array}{l}\text { Al-mghashe } \\
\text { "previously } \\
\text { 17th july" }\end{array}$ & Dhi-Qar & Tigris & $\mathrm{D}$ & 56 & 56 & 0 & 56 & 49.1 & $100 \%$ & 167.2 & 3403.714 & 23.2 & 8.95 \\
\hline 111 & East gharaf & Wasit/Dhi-Qar & Tigris & 24 & 475 & 55 & 400.7 & 455.7 & 399.7 & $96 \%$ & $1,367.50$ & 3421.001 & 193 & 74.46 \\
\hline 112 & $\begin{array}{l}\text { Dawaiyah } \\
\text { "previously } \\
\text { 30th july" }\end{array}$ & Misan/Dhi-Qar & Tigris & 11 & 183 & 123 & 60 & 183 & 160.5 & $100 \%$ & 567.9 & 3537.738 & 79.9 & 30.83 \\
\hline 113 & Dujailah & Wasit & Tigris & $\mathrm{D}$ & 186 & 186 & 0 & 186 & 163.2 & $100 \%$ & 556.4 & 3410.194 & 81.7 & 31.52 \\
\hline 114 & Kut-butaira & Wasit/Misan & Tigris & 20 & 133 & 16 & 117 & 133 & 116.7 & $100 \%$ & 393.3 & 3371.143 & 60.1 & 23.19 \\
\hline 115 & Abu-bshoot & Misan & Tigris & $\mathrm{D}$ & 29 & 29 & 0 & 29 & 25.4 & $100 \%$ & 88.7 & 3486.828 & 12.9 & 4.98 \\
\hline
\end{tabular}




\begin{tabular}{|c|c|c|c|c|c|c|c|c|c|c|c|c|c|c|}
\hline 116 & Taib & Misan & $\begin{array}{l}\text { Eastern } \\
\text { Tributaries }\end{array}$ & 2 & 1 & & 1 & 1 & 0.9 & $100 \%$ & 2.8 & 3192 & 0.4 & 0.15 \\
\hline 117 & Duwairij & Misan & $\begin{array}{l}\text { Eastern } \\
\text { Tributaries }\end{array}$ & 1 & 3 & & 3 & 3 & 2.6 & $100 \%$ & 7.2 & 2736 & 1.1 & 0.42 \\
\hline 118 & Nahar-saad & Misan & Tigris & $\mathrm{D}$ & 75 & 75 & 0 & 75 & 65.8 & $100 \%$ & 215.7 & 327.64 & 31.1 & 12.00 \\
\hline 119 & Amara & Misan & Tigris & 7 & 400 & & 400 & 400 & 350.9 & $100 \%$ & $1,118.40$ & 3187.44 & 159.3 & 61.46 \\
\hline 120 & $\begin{array}{l}\text { Shatt al- } \\
\text { arab \& } \\
\text { swaib }\end{array}$ & Basrah & Tigris & 66 & 290 & 20 & 130 & 150 & 131.6 & $52 \%$ & 404.8 & 3076.48 & 70.3 & 27.12 \\
\hline 121 & $\begin{array}{l}\text { Zubair } \\
\text { (irrigated } \\
\text { from wells) }\end{array}$ & Basrah & GW-wells & GW & 35 & & 35 & 35 & 30.7 & $100 \%$ & 99.5 & $\begin{array}{c}32400.85 \\
7\end{array}$ & 18.4 & 7.10 \\
\hline 122 & $\begin{array}{l}\text { Modern } \\
\text { village } 1 \\
\text { and } 2\end{array}$ & Baghdad & Tigris & 50 & 60 & & 60 & 60 & 52.6 & $100 \%$ & 156.1 & 2965.9 & 23.3 & 8.99 \\
\hline 123 & Basroukiya & $\begin{array}{l}\text { Diwaniyah } \\
\text { Muthanna }\end{array}$ & Tigris & 10 & 94 & & 94 & 94 & 82.2 & $100 \%$ & 273.9 & 3321.766 & 38.4 & 14.81 \\
\hline 124 & $\begin{array}{l}\text { Mdalel, } \\
\text { mrezeja and } \\
\text { fao }\end{array}$ & $\begin{array}{l}\text { Diwaniyah } \\
\text { Muthanna } \\
\text { Wasit } \\
\text { Diwaniyah } \\
\text { Dhi- Qar }\end{array}$ & Tigris & 9 & 12 & & 12 & 12 & 10.5 & $100 \%$ & 35.5 & 3353.5 & 4.9 & 1.89 \\
\hline 125 & Abbasi & $\begin{array}{l}\text { Kirkuk } \\
\text { Salah-addin }\end{array}$ & Tigris * & 34 & 60 & & rainfed & & 0.0 & & & & & 0.0 \\
\hline 126 & Sader & $\begin{array}{l}\text { Erbil/Kirkuk } \\
\text { Salah-ad-din }\end{array}$ & Tigris & 28 & 150 & & 20 & 20 & 17.5 & $13 \%$ & 44 & 2508 & 7.6 & 2.93 \\
\hline 127 & $\begin{array}{l}\text { Ali gharbi } \\
\text { and ali } \\
\text { sharqi }\end{array}$ & Misan & Tigris & 3 & 137 & & 137 & 137 & 120.2 & $100 \%$ & 403.4 & 3356.759 & 6207 & 24.19 \\
\hline 128 & Boghaylat & $\begin{array}{l}\text { Misan } \\
\text { Dhi-Qar }\end{array}$ & Tigris & 6 & 30 & & 30 & 30 & 26.3 & $100 \%$ & 93.4 & 3549.2 & 13.2 & 5.09 \\
\hline 129 & 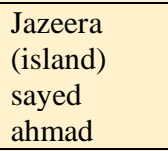 & $\begin{array}{l}\text { Misan } \\
\text { Dhi-Qar }\end{array}$ & Tigris & 5 & 40 & & 40 & 40 & 35.1 & $100 \%$ & 123.3 & 3514.05 & 17.4 & 6.41 \\
\hline 130 & $\begin{array}{l}\text { Southern ez } \\
\text { river }\end{array}$ & Misan & Tigris & 4 & 17 & & 17 & 17 & 14.9 & $100 \%$ & 45 & 3017.647 & 7.7 & 2.97 \\
\hline 131 & Khozaimiya & Salah-ad-din & Tigris & 29 & 5 & & 2 & 2 & 1.8 & $40 \%$ & 4.9 & 2793 & 0.8 & 0.31 \\
\hline
\end{tabular}




\begin{tabular}{|c|c|c|c|c|c|c|c|c|c|c|c|c|c|}
\hline 132 & $\begin{array}{l}\text { Jazeera } \\
\text { western } \\
\text { samarra }\end{array}$ & Salah-ad-din & Tigris & 49 & 89 & 89 & 89 & 78.1 & $100 \%$ & 220.9 & 2829.506 & 37.5 & 14.47 \\
\hline 133 & $\begin{array}{l}\text { Upper } \\
\text { resasy }\end{array}$ & Salah-ad-din & Tigris & 44 & 18 & 18 & 18 & 15.8 & $100 \%$ & 45.8 & 2900.667 & 7.8 & 3.01 \\
\hline 134 & $\begin{array}{l}\text { Southern } \\
\text { haseeba al } \\
\text { baghouz }\end{array}$ & Anbar & Euphrates * & 59 & 4 & rainfed & & 0.0 & & & & & 0.0 \\
\hline 135 & $\begin{array}{l}\text { Expanding } \\
\text { hilla } \\
\text { hashimiyah }\end{array}$ & $\begin{array}{l}\text { Babil } \\
\text { Diwaniyah }\end{array}$ & Euphrates & 46 & 150 & 150 & 150 & 131.6 & $100 \%$ & 361.8 & 2749.68 & 50.5 & 19.48 \\
\hline 136 & $\begin{array}{l}\text { Extension } \\
\text { sewaer }\end{array}$ & Muthanna & Euphrates & 16 & 43 & 43 & 43 & 37.7 & $100 \%$ & 129.3 & 3427.953 & 18.8 & 7.25 \\
\hline 137 & $\begin{array}{l}\text { Extension } \\
\text { Middle } \\
\text { Tigris- }\end{array}$ & Wasit & Tigris & 36 & 137 & 137 & 137 & 120.2 & $100 \%$ & 374.1 & 3112.949 & 51 & 19.68 \\
\hline 138 & Al Gharbia & Wasit & Tigris * & 32 & 40 & rainfed & & 0.0 & & & & & 0.0 \\
\hline 139 & $\begin{array}{l}\text { Kirkuk } \\
\text { Phase } 3 \\
\end{array}$ & $\begin{array}{l}\text { Salah-ad- } \\
\text { din/Diyala }\end{array}$ & Udhaim & 22 & 160 & 160 & 160 & 170.4 & $100 \%$ & 313.8 & 2235.825 & 54.3 & \\
\hline 141 & $\begin{array}{l}\text { Farms in the } \\
\text { north of } \\
\text { Saqlawiya }\end{array}$ & Anbar & Euphrates & 26 & & 26 & 26 & 22.8 & $100 \%$ & 68.3 & 2994.692 & 11.2 & \\
\hline 142 & $\begin{array}{l}\text { Is'haqi } \\
\text { farms from } \\
\text { Balad up to } \\
\text { the } \\
\text { confluence } \\
\text { with Tigris } \\
\text { arm }\end{array}$ & $\begin{array}{l}\text { Salah-ad-din } \\
\text { Baghdad }\end{array}$ & Tigris & & 62 & 62 & 62 & 54.4 & $100 \%$ & 147.4 & 2710.258 & 25 & \\
\hline
\end{tabular}




\section{Recommendations for implementing land reclamation projects}

As the reclamation projects are costly projects and require large sums, and for the purpose of accelerating the reclamation of large areas, especially in central and southern Iraq, during an appropriate period, the following methods can be proposed for this purpose:

1. The governments' reclamation of lands belonging to the owners of agricultural properties by referring them to contracting and allocating the necessary amounts for them and after the completion of the reclamation work, the amounts spent on these works are recovered from the owners of agricultural properties after an appropriate period of investment, and the recovery is either in cash or in a certain percentage of the productive agricultural crops, and the government may obtain loans from international financial institutions to finance some projects

2. Carrying out reclamation projects under investment by local and foreign investors and companies, so that the investor undertakes the implementation of the integrated reclamation work of the project and then invests it for certain years and under certain conditions specified in investment contracts, and this applies to state- owned lands. The investment contract should stipulates the employment of the farmers and contractors in the project as part of the agricultural reclamation and investment works until the project is handed over to the government, which in turn returns these lands to the agricultural contracting farmers in the project, and here the farmer has gained experience and the method of work from the agricultural investor.

3. Involving agricultural engineers and graduates of agricultural institutes to invest in lands that are reclaimed by investors for the purpose of cultivating it and forming agricultural societies from them to assume this task, provided that these societies undertake work with investors during the implementation of the reclamation work and during the period of cultivation and productive agriculture and prepare a form of law and instructions for this purpose.

4. Stages of reclamation works must be integrated ( study, design, implementation, washing, farming ).

5. Focusing on applied scientific research in the fields of irrigation, soil and land reclamation, the results are reflected in the development of reclamation methods, shortening the implementation period, reducing the cost and improving the capabilities of reclaimed lands, as well as training engineering and intermediate personnel in operating and maintaining irrigation and drainage networks. 


\section{References}

[1] Abu-Gullal, Kanaan Abduljabar, Faisal Kadhum, Al-Athari, and Bassam, Kanaan Abu-Gullal (2017). Design Principles for Irrigation Canals and Farm Irrigation Systems. Baghdad: Thair Al-Isami.

[2] Abu-Gullal and Kanaan, Abduljabar (2019). Integral Water Resources Management in Iraq. Baghdad.

[3] Al-Simawi, H. (2008). Encyclopedia of Dams in Iraq.

[4] Al-Simawi, H. (2010). Irrigation and Drainage Projects in Iraq.

[5] Allen, R.G, Luis, S. P., Raes, D. and Smith, M. (1998). FAO Irrigation and Drainage Paper No. 56. Rome: Food and Agriculture Organization of the United Nations, 56 (97): e156.

[6] Dieleman, P. J. and Roumans, J.H. (1963). Reclamation of Salt Affected Soils in Iraq. H. Veenman.

[7] Directorate General of Irrigation (1954). Report about Directorate General of Irrigation Works for a Five Years from 1949 to 1954 (in Arabic).

[8] JICA, Japan International Cooperation Agency (1977). Preliminary Survey Report on Agricultural Development Project in the Republic of Iraq.

[9] JICA (2016). Data Collection Survey on Water Resource Management and Agriculture Irrigation in The Republic of Iraq: Final Report.

[10] Resources, Ministry of Water (2005). The Encyclopedia of Irrigation in Iraq, February 1918-February 2005. 